\title{
The Ethics and Integrity of Cataloging
}

\section{Anna M. Ferris}

To cite this article: Anna M. Ferris (2008) The Ethics and Integrity of Cataloging, Journal of Library Administration, 47:3-4, 173-190, DOI: 10.1080/01930820802186514

To link to this article: https://doi.org/10.1080/01930820802186514

曲 Published online: 12 Oct 2008.

6 Submit your article to this journal $\pi$

山ll Article views: 526

Citing articles: 3 View citing articles 


\title{
The Ethics and Integrity of Cataloging
}

\author{
Anna M. Ferris
}

\begin{abstract}
Through a review of the professional values and responsibilities with which catalogers identify most, i.e., patron service and the integrity of the catalog, this paper explores the significance of the professional catalogers' role when faced with major challenges to their ability to provide service and maintain the integrity of the catalog.
\end{abstract}

KEYWORDS. Cataloging, ethics, values, librarianship, bibliographic control, catalogers' judgment

"Ethics is a social matter, concerning the obligations of individuals to others, a set of shared expectations about each other, and the world we share." 1

\section{LIBRARIANS AND ETHICS}

Librarianship is quintessentially a service profession. The role and the duties of professional librarians are based on their obligation to serve the needs of a library's patrons. For good reason, the key areas within a library are often called public services, reference services or technical services; and an important aspect of an academic librarian's job is dedicated to professional service. With such a commitment to service, it follows that the professional librarian is guided by a high sense

Anna M. Ferris is Assistant Professor and Head of Special Collections \& Archives Cataloging, University Libraries, University of Colorado at Boulder, 184 UCB, Boulder, Colorado 80309-0184 (E-mail: nna.ferris@ colorado.edu).

The author is indebted to Christopher Cronin for his editorial and ethical guidance.

Available online at http://jla.haworthpress.com

(C) 2008 by The Haworth Press. All rights reserved. doi:10.1080/01930820802186514 
of ethical obligation. In fact the following definition of ethics could easily be used to define the role of the professional librarian as well: "Ethics is concerned with personal conduct and ethical behavior that defines a high standard of personal responsibility. Acting ethically means making decisions based on principles of responsiveness, fairness, efficiency, expertise, service, and security."2

As individuals, librarians hold their own personal views on what constitutes ethical behavior, but librarians are also taught about the importance of ethics in the context of librarianship while in library school. In particular, they learn about the conflicts of interest that may arise when librarians are placed in situations where their judgment is challenged while providing service to the patrons of the library-for example, when reference librarians are asked to provide confidential patrons' records; when acquisitions librarians are offered gifts when negotiating contracts with vendors; or when demands are made upon media specialists to ban certain children's books from their collections. In recent years, highly publicized cases involving the implementation of the U.S. Patriot Act and the Children's Internet Protection Act have required librarians to voice their concerns about ethical issues. Within the American Library Association (ALA), the Social Responsibilities Round Table (SRRT), with a current membership of $2,176,{ }^{3}$ provides a public forum for librarians to discuss their professional obligations in the context of the ethical challenges librarians now face.

\section{CODES OF ETHICS FOR INFORMATION PROFESSIONALS}

Organizations of information professionals (which also include librarians) have realized the need to provide formal codes of ethics to direct their members when conflicts of interest must be resolved. Taylor points out, "In the complex society in which we live, information technology professionals are sometimes faced with predicaments in which it is difficult to decide what is the "right' thing to do." 4 Some of these organizations include: the Association for Computing Machinery (ACM), ${ }^{5}$ the Association of Independent Information Professionals (AIIP), ${ }^{6}$ the American Society for Information Science and Technology (ASIS\&T), ${ }^{7}$ the American Society for Public Administration (ASPA), ${ }^{8}$ the Society of Competitive Intelligence Professionals (SCIP), ${ }^{9}$ the Society of American Archivists (SAA), ${ }^{10}$ and the American Library Association (ALA). ${ }^{11}$ The guidelines offered by many of these organizations are remarkably similar. Some of the principles they have in common 
are: (1) providing the highest quality of service; (2) maintaining professional competence; (3) honoring confidentiality; (4) refraining from advancing personal interests; (5) applying fair business practices; (6) promoting equal access and intellectual freedom; and (7) maintaining collegial relationships.

While the general purpose of a code of ethics is to guide professionals to make sound decisions in situations of ethical conflict, it is important to note that guidance may not always be available for every situation. One may question the usefulness of such generalized codes for professional librarians with specialized skills and job responsibilities. The ALA's Code of Ethics has been criticized for offering too generalized a view for professional librarians to follow since the ALA code encompasses all types of library information providers, including paraprofessionals, library workers, administrators as well as professional librarians. Concerning highly-skilled professional librarians, Bierbaum and ALCTS recognized the need to offer a code of ethics for technical services ${ }^{12}$ and acquisitions librarians, ${ }^{13}$ respectively. More specifically, Bair understood that "... catalogers are professionals with special skills that set them apart from the profession in general and give them unique ethical responsibilities"14 and proposed a formal code of ethics for cataloging.

It is worth noting that, despite the existence of numerous codes of ethics for information professionals, including librarians and catalogers, compliance with ethical codes is left entirely up to the discretion of the individual. When the ALA Code of Ethics was published in 1995, the Committee on Professional Ethics issued a report to the ALA Council which stated: "a professional code of ethics by its very nature ought to be voluntary, and should not have the force of any 'legal' weight behind it ... enforcement of the code is a moot point."15

\section{GOING BEYOND CODES OF ETHICS FOR CATALOGERS}

In situations where catalogers with specialized skills are not able to resolve conflicts of interest by referring to a code of ethics, guidance can be sought from other catalogers or managers who may have had experience in resolving such conflicts. In this context, such a situation is illustrated in a fictional case study by Fay Zipkowitz in which a copy cataloger is resistant to cataloging works that she finds objectionable-for example, a book claiming that the Holocaust never happened; and a book by a TV evangelist who claims that AIDS can be transmitted 
through the mail. She proposes to the Head of Cataloging that she alter each catalog record to indicate that the content is not authentic or is the product of warped minds. The Head, upon examining each work, finds that the catalog records are usable LC-copy (i.e., complete and authorized according to the standards of the Library of Congress). He reminds the copy cataloger that the library's policies are to accept the catalog record unless there are serious errors. They are not to pre-censor anything in the library, should avoid providing viewpoints on a particular topic, and are to let the reader decide what is true or not true. ${ }^{16}$

This example demonstrates that catalogers have an ethical obligation to serve the needs of other catalogers, other librarians, and their institution as well as the general users of the library's catalog. Yet, it is important to point out that, beyond an ethical obligation to serve, there are other professional obligations at work defining the role and duties of practicing catalogers. In the following sections, we will explore what the professional priorities are for librarians in general and then explain what constitutes the highest priority for catalogers in particular.

\section{PROFESSIONAL PRIORITIES FOR LIBRARIANS}

\section{Values}

In the library literature, the subject of values is closely linked to discussions about ethics in librarianship. Gorman has defined a value as, ". . . something that is of deep interest (even self-interest) to an individual or a group. ... [T] he individual has to believe and hold a value before she or he can associate with others who hold the same values to form a community of interest." 17 Peterson explains that: "All human beings have a set of values ... It has long been one of the recognizable signs of a professional group that it have a code of ethics or commonly held standards of professional behavior." 18 While professional librarians may have issues with the ALA's Code of Ethics, most nevertheless recognize a set of core professional values. In a survey of information workers, Koehler identified the following 11 core professional values identified by librarians: (1) service to the client, (2) equality of access, (3) information literacy, (4) intellectual freedom, (5) preservation of the cultural record, (6) literacy, (7) professional neutrality, (8) diversity of opinion, (9) confidentiality of records, (10) cultural diversity, and (11) copyright and intellectual property rights. ${ }^{19}$ 
In a related study, Dole observes that the most identified value among academic librarians in North America was patron service. In addition, she reports that "there is differentiation of values among librarians ... [ [which is] . . . probably a function of the different information roles and responsibilities of these information professionals." 20 Gorman's definition of librarianship describes what these roles and responsibilities are: "Librarianship [is] the field of professionals who (1) assemble and give access to selected sub-sets of the human record; (2) organize and list those sub-sets so they can be retrieved; (3) give help and instruction in the use of the human record; (4) work to ensure that the records are integrated to allow universal access to the whole human record; and (5) are dedicated to the preservation and onward transmission of the human record." 21

\section{ROLES AND RESPONSIBILITIES}

Gorman also stresses the importance of our role in passing on the $h u$ man record-"that vast assemblage of messages and documents (textual, visual, sound and symbolic) in all formats created by humans since the invention of written and visual communication millennia ago"22-because this is the one activity that distinguishes us from all other information professionals. As professional librarians, we have a vested interest in seeing that each of these responsibilities is carried out as competently as possible. Yet few librarians are entrusted with each of these responsibilities at the same time (unless they are school media specialists or special librarians working solo in a corporate library). It is the acquisition librarian's responsibility, for example, to assemble and give access to selected sub-sets of the human record, the reference librarian's responsibility to give help and instruction in the use of the human record, and it is the cataloger's responsibility to organize and list those sub-sets of the human record so they can be retrieved. These are the different information roles and responsibilities to which Dole was referring. The differentiation of values, on the other hand, explains why the members of SRRT, mentioned earlier, are compelled to join like-minded colleagues in defending the values that define their particular job responsibilities. For example, it is understandable that archivists would identify predominantly with preservation of the cultural record; or that school media specialists would rank information literacy above the other values; or that law librarians would identify most with intellectual property rights. Academic librarians believe that patron service is their most fundamen- 
tal value. Yet, where catalog librarians are concerned, there may still be further differentiation found among academic librarians. We propose that there is an additional core professional value for which catalogers have a deep-seated commitment and that identifies their primary responsibility as librarians: the promotion and preservation of the integrity of the catalog.

\section{PROFESSIONAL PRIORITIES FOR CATALOGERS}

\section{Bringing Order to Chaos}

Of Gorman's five fundamental responsibilities of librarianship, the one that distinguishes catalogers from other librarians is their role in organizing information so that it can be useful to the persons seeking that information. There are two specific processes by which this task-commonly referred to as bringing order to chaos-is accomplished: bibliographic control and catalogers' judgment.

\section{Bibliographic Control}

The process of bibliographic control involves the following steps: (1) evaluating an item to determine the level of description required; (2) describing it in a unique catalog record; (3) identifying the significant aspects of its content; and (4) collocating it with other similar pieces of information so that it can be easily located and retrieved when searched in the library's catalog or browsed on the shelf.

Through the years catalogers have refined the process of bibliographic control and, at each step, have documented the rules and standards of practice for other catalogers to follow. The process continues to be a flexible one as witnessed by the remarkable changes to cataloging codes and practice that have occurred in the last few decades. For example, bibliographic control has accommodated innovations in technology and the effects of global interconnectedness and, as a result, has become a more effective process as standards have become internationalized. Additionally, national databases and union catalogs have expanded in scope, local cataloging systems have been automated and made accessible on the Web, and libraries' holdings now encompass virtual as well as physical collections.

The value of bibliographic control is that it assures timely access to specific pieces of information being sought by users of the library's cat- 
alog. More importantly, because the information has received bibliographic control, users can be confident that the information they retrieve is relevant to their needs as well as objective and reliable in its stated content. What is more, bibliographic control is one of the important ways that the practicing cataloger provides a direct service to the users of the catalog.

\section{Catalogers' Judgment}

Another way that catalogers contribute to the organization of information is through exercising their own catalogers' judgment. That is, the level of expertise attained by each cataloger after years of having interpreted and applied the principles of bibliographic control. Santamauro and Adams explain: "While catalogers" judgment is often assumed to be common sense, it is actually the result of cataloging culture, hands-on experience, and education." 23 The value of catalogers' judgment is that it supports the idea that one size does NOT fit all in applying the rules of bibliographic control. The expert cataloger recognizes that blind adherence to the rules does not always lead to better access. Holley observes that "The emphasis [is] on problem solving and on understanding the larger issues rather than on mastering small, picky points." 24 On a related note, an in-depth exploration of the validity of standardized cataloging data from bibliographic utilities was the subject of the conference, Cataloging Heresy: Challenging the Standard Bibliographic Product, held at St. Johns University in 1991. The conference chair, Bella Hass Weinberg concludes that, "Centrally supplied bibliographic data must be evaluated by the local library ... this assumes mastery of cataloging and classification theory by the local cataloger and the wisdom to modify the central bibliographic record when this is in the best interests of the library's user community." 25

Given that a differentiation of roles and responsibilities exists even among practicing catalogers (e.g., the copy cataloger, the original cataloger, the monographic cataloger, the serials cataloger, and the special formats cataloger), each cataloger is likely to follow prescribed procedures that may differ from those of the other catalogers. For example, when transcribing titles monographic catalogers are instructed to use the title page of the item in-hand as the chief source of information, whereas catalogers of archival collections are instructed to treat the whole collection as the chief source. Santamauro and Adams observe that: "There is often more than one way to accurately describe a resource. ... The essence of catalogers' judgment is the idea that a different choice is not a mistake. Sometimes cataloging is about following specific cataloging codes and other issues can only be solved by making 
a subjective decision." 26 It is the cataloger's specialized viewpoint that permits him or her to know how best to interpret a rule-one could say to bend the rule-in order to enhance access for the users of the library's catalog. In a sense, by applying catalogers' judgment, the individual cataloger is providing an "added value" to the process of bibliographic control. This is not an insignificant contribution on the part of the cataloger in fulfilling his or her responsibility to help users find what they need.

\section{THE INTEGRITY OF THE CATALOG}

As seen earlier, the promotion and preservation of the integrity of the catalog is the core value that defines the raison d'être of the practicing cataloger. (The term integrity is used because it connotes consistency, dependability, and reliability.) The catalog, without a doubt, represents what is of deepest interest (even self-interest according to Gorman) to all catalogers. It is the result of years of mastered principles and practices that catalogers have used to bring order and significance to recorded instances of the human record. The existence of the catalog justifies the cataloger's own existence as a highly skilled member of a learned profession.

Yet, in their daily routines, catalogers rarely have the opportunity to interact directly with the users of the library's catalog as their public services colleagues do. Instead, catalogers interact directly with the cata$\log$ on behalf of the users (who, incidentally, also include their public services colleagues). They are, according to Iliff, "the architects, construction workers, and maintenance workers of the information infrastructure that we call our library catalogs." 27 With such an in-depth knowledge of the catalog, one can understand why catalogers would be so committed to ensuring that it continues to be the place that patrons will turn to in order to find information that is reliable, timely and relevant to their needs.

\section{ETHICAL SHORTCOMINGS OF CATALOGING CODES AND STANDARDS}

An important aspect of preserving the integrity of the catalog concerns the catalogers' ability to impact the accessibility and quality of the information being cataloged. Bair states, "Catalogers recognize and accept the privilege and responsibility that is ours as gatekeepers of infor- 
mation and architects of the information infrastructure to provide fair and equitable access to relevant, appropriate, accurate and uncensored information in a timely manner and free of personal or cultural bias." 28 Over the years, critics have questioned the use of cataloging policies and practices that have impeded access or encouraged biases in information.

For example, in 1991, examples of objectionable applications of cataloging rules and standards were published in the proceedings of the Cataloging Heresy conference mentioned earlier. Berman, ${ }^{29}$ Nuckolls, ${ }^{30}$ and others have been outspoken about the Library of Congress Subject Headings' (LCSH) use of biased terminology. The following section highlights some examples of the more representative issues.

\section{Issues with Descriptive Cataloging Rules}

Anderson observes that "our cataloging rarely takes account of the different canons of the different religious traditions. . . . Instead, it glosses over the differences and adopts terminology that fits no tradition in any consistent way." 31 For example, based on rule 25.18.A5 from the Anglo-American Cataloguing Rules, 2nd ed., 2002 revision, (AACR2), Apocrypha is to be used for "collections of texts of those books excluded from only the Protestant and Jewish canons of the Old Testament." 32 Based on AACR2 rule 25.18.A14, Apocryphal books is to be used for "collections of texts of those books excluded from both the Catholic canon and the Protestant and Jewish canons of the Old Testament and from the Catholic and Protestant canons of the New Testament."33

Problem: Patrons may find it difficult to locate particular religious works, unless they know beforehand which version of a Bible has been defined by a specific religion.

Resolution: A resolution is yet to be found for this problem.

Olson identifies problems of cataloging three-dimensional artifacts and realia as a result of the minimal treatment given these materials in Chapter 10 of the AACR2. She provides detailed guidelines in "Cataloging Three-Dimensional Artifacts and Realia."34

Resolution: Other cataloging communities have developed standards to deal with the cataloging of non-bibliographic format-specific materi- 
als, i.e., Describing Archives: A Content Standard (DACS) for archival collections; Cataloging Cultural Objects: A Guide to Describing Cultural Works and Their Images (CCO) for art and architectural visual resources.

\section{Issues with Subject Analysis Rules}

Library of Congress subject headings have traditionally been based on the concept of literary warrant. In other words, the terms used in their controlled vocabulary thesaurus were formulated exclusively from LC's own collections of cataloged materials of mostly American publications intended for an average reader who, as Marshall observes, to a large extent, "has been identified as American/Western European, Christian, white, heterosexual and male." 35

Problem: Libraries with collections of materials outside the American mainstream were at a disadvantage when trying to apply the LCSH for their own specialized purposes.

Resolution: Today, LC accepts subject headings based on the collections of other libraries who contribute new headings as participants of LC's cooperative cataloging programs.

Olson identifies two problems with LC subject headings-(1) a lack of inclusive language and (2) sex-biased assumptions reflected in the choice of terms. In the first case, Olson objects to the use of Man, a male-as-normative term, to describe all of humanity. In the second case, the term Contraception points to a narrower term, Male contraception, but there is no equivalent term for $\mathrm{Fe}$ male contraception. Olson concludes that, "Here LCSH is undoubtedly reflecting the societal assumption that contraception is a female responsibility, while male contraception is exceptional." 36

Resolution: The use of the heading (Man), to describe humanity, has since been changed to Human Beings in the LCSH. (There is still no subject heading for Female contraception.)

\section{Issues with LC as the Cataloging Standard}

For years, LC's descriptive cataloging policies and practices have been accepted as the de facto standard for bibliographic control by libraries and library networks across the United States. This is understandable since LC developed the standards and systems it needed to 
organize its own collection of national repository materials at a time when there were no comparable standards or systems available. In 1991, Sheila Intner questioned the logic of such a widespread adoption of LC's practices since "what the Library of Congress does for itself is not necessarily the best thing for all other libraries in the nation. ... The environment, patrons, resources, and goals of most individual libraries differ considerably from those of the Library of Congress." 37

\section{LC Series Decision}

Today, the prescience of Intner's observation is noteworthy in light of the recent decision (in June 2006) by LC cataloging directors to discontinue the practice of tracing series in bibliographic records. (Tracing refers to the process of providing controlled access to the title of a bibliographic series in a catalog record by linking it to a unique series authority record (SAR) in the LC Name Authority File). For those catalogers who perform series authority control and contribute SARs to the National Authority File on a regular basis, the decision by LC to discontinue such an efficient mechanism for collocating related titles constitutes a drastic move. The dilemma for many catalogers, besides the fact that LC chose to give little advanced notice of their decision, is reflected in the statement issued by the Board of Directors of the Association for Library Collections \& Technical Services (ALCTS): "Libraries accepting unedited LC copy will now lose controlled series access in their catalogs. If they elect to take on this task themselves, it will mean a great deal of labor intensive checking and editing of records-labor that was not previously needed." 38 In addition, LC was seen to be relinquishing its leadership role in bibliographic control, a role it had historically performed for close to a century.

In fairness to LC, the decision to discontinue a practice that has a limited application for select sets of bibliographic materials is an example of what LC has been doing for many years-taking the initiative to develop policies and practices that affect its own collections of institutional repository (in this case, congressional) materials. In its own way, LC is responding to the shift that has occurred in the way its patrons search for and expect to find information, in other words, remotely and instantaneously. Patron preferences have shifted away from a bibliocentric model for information retrieval (the status quo for many librarians) to a pervasively electronic model characterized by "the userdriven, participatory, personalized Web as manifested in such sites as MySpace, ... Wikipedia, and other online gathering places." 39 The fact 
that many catalogers may be finding it difficult to make the shift as LC has done is an ethical dilemma that each cataloger is forced to resolve individually.

\section{Steps Being Taken Towards Ethical Resolutions}

As noted in some of the examples above, catalogers have been able to resolve many of the more objectionable misapplications of cataloging rules and standards.

Regarding the LCSH, Steven A. Knowlton reports on the changes implemented since the publication of Berman's critique: "Concentrated attention to the issue of bias in LCSH has borne fruit in the three decades since the publication of [Prejudices and Antipathies], and the library community can point to these precedents as hopeful milestones in the continuing effort to provide equal access to all users." 40

The Library of Congress continues to be amenable to revising the LCSH as witnessed by a major change announced earlier this year at the American Library Association 2007 Midwinter conference in Seattle, Washington:

"[R]ecognizing the increased diversity in religious backgrounds of Americans and other populations that use LCSH, CPSO [Cataloging Policy and Support Office] revised headings for God to provide a distinction in access between general and comparative works (under the unqualified heading God) and works from a Christian perspective (under the heading God (Christianity)). These provisions provide a uniform treatment for the concept in all religions, since the headings for other religions were already established as God (Islam); God (Judaism); etc."41

Regarding the LC decision to discontinue series authority control, a general outcry and numerous discussions from catalogers around the world resulted in a formal petition, Prevent the Library of Congress From Abandoning the Creation of Series Authority Record, decrying the LC decision. ${ }^{42}$ As a result, practicing catalogers who are members of the Program for Cooperative Cataloging (PCC) have agreed to maintain the policies and practices of series authority control and to continue contributing SARs to the series author- 
ity file. In support of this move, OCLC has agreed to retain the controlled series access fields used for that purpose in MARC formatted bibliographic records.

Regarding the AACR2 descriptive cataloging rules, catalogers from a variety of cataloging communities (e.g., libraries, archives, museums, publishers, etc.) are developing a new descriptive cataloging code, Resource Description and Access (RDA), to replace the predominantly bibliocentric codes in the AACR2. RDA is being described as "a new standard designed for the digital environment ... includ[ing] guidelines and instructions that would cover description and access for all digital and analog resources, resulting in records that could be used in a variety of digital environments (the Internet, Web OPACs, etc.)." 43 In spite of this forwardthinking approach, there are conflicting views within the ranks of the revisors as to how drastic the revision of the rules should be. Coyle and Hillman, proponents of the Web-centric model for transmitting information resources, write: "The library's signature service, its catalog, uses rules for cataloging that are remnants of a long departed technology: the card catalog. Modifications to the rules, such as those proposed by the Resource Description and Access (RDA) development effort, can only keep us rooted firmly in the 20th, if not the 19th century. A more radical change is required that will contribute to the library of the future, re-imagined and integrated with the chosen workflow of its users." 44

\section{CONCLUSION}

The ethics of cataloging comes down to one thing-the cataloger's personal obligation to bring order to information and to make it accessible to the persons seeking that information. The role catalogers play in organizing and providing access to information is their most significant contribution in serving the needs of the library's patrons. However, catalogers also have a fundamental obligation to preserve the integrity of the catalog. By so doing, they are ensuring that the library's catalog is a reliable source of current, coherent, and objective information that is appropriate to the needs of the catalog's users.

The significance of what catalogers do in order to meet their users' needs is the subject of The Value of Cataloging Librarians, a document published by the ALCTS CCS Executive Committee. This document emphasizes the various roles catalogers play as leaders, collaborators, 
creators, and facilitators of access who are committed to professional development. The document lists the activities performed by catalogers, some of which include:

- [Cataloging librarians] envision bibliographic control . . . to create . . c catalogs and digital access systems.

- Create standards ... [including] newer metadata standards . . . by working with national and international organizations.

- Work with digital library projects to develop local policies and to create metadata records, following local and international standards.

- Contribute to the creation and ongoing development of international databases, catalogs and authority files.

- Describe and provide access to ... unique items in special formats and foreign languages, and items of local interest.

- Educate themselves in new technologies and changing standards and apply those ... to local workflows.

- Work collaboratively in local, regional, national and international groups, both in person and online, to solve problems, learn, grow and develop. ${ }^{45}$

These activities show the critical role that practicing catalogers play in enhancing the functionality of the catalog. As experts in bibliographic control, capable of implementing the newest standards and technologies, catalogers have succeeded in transforming the library's catalog into a dynamic, all-purpose research tool that is continually being tailored to accommodate user preferences.

Catalogers have modified their library's catalog to accommodate patron needs since the turn of the century. Decades ago, catalogers served their local patrons exclusively by means of hand-typed catalog cards representing their local collections. With the advance of automation (i.e., the MARC format) in the 1960s, catalogers could share catalog records through national bibliographic utilities and thereby expose their collections to a broader group of catalog users. The scenario has changed significantly for catalogers these days as patrons' expectations and search habits have shifted away from a bibliocentric model for information retrieval. As Coyle and Hillman observe, "Today's library users have a different set of information skills from those of just a few decades ago. They live in a highly interactive, networked world and routinely turn to Web search engines for their information needs." 46 Attuned to the changes in patrons' needs, catalogers have enhanced catalog records to include extensive tables-of-contents, abstracts that allow for 
detailed keyword searches, links to remote digital repositories and to related resources such as digital images and audio recordings.

It is important to note that the codes and standards for bibliographic description have undergone changes comparable to the modifications made to the public interface of the library's catalog. In the early 1900s, catalogers looked to the LC cataloging rules and standards for guidance when cataloging their own local collections. With the shift to cooperative cataloging in the 1990s, new cataloging guidelines were developed by the PCC for the participants of their various programs: the Monographic Bibliographic Record Program (BIBCO), the Name Authority Cooperative Program (NACO), the Subject Authority Cooperative Program (SACO), and the Cooperative Online Serials Program (CONSER). Recent innovations in digital technology and new access systems have obliged catalogers to undertake a major revision of the outdated AACR2 code and to draft a new code (RDA). New standards have also been developed by other cataloging communities (Dublin Core (DC), VRA Core, PBCore and CCO) to process the growing number of media and Web resources being sought through the library's catalog.

Out of a personal sense of obligation, catalogers render the extremely valuable service of "passing on the human record" 47 to those who seek it. Through their efforts to preserve the integrity of the catalog for the benefit of their library's patrons, catalogers embody Gorman's sentiment in his President's Message editorial in American Libraries: "The ultimate state of being to which we should aspire and to which all our effort should be directed is universal access to high-quality library services." 48

\section{NOTES}

1. Geoffrey Vickers, Human Systems are Different (London: Harper \& Row, 1983).

2. Florence Mason, "Ethics and the Electronic Society," from Thinking Robots, an Aware Internet, and Cyberpunk Librarians, ed. by R. Bruce Miller and Milton T. Wolf (Chicago: Library and Information Technology Association, 1992).

3. Alison Lewis, SRRT coordinator, e-mail message to author, July 30, 2007.

4. M. J. Taylor, M. J. and E. Moynihan, "Analysing IT ethics," Systems Research and Behavioral Science 19 (2002): 49. DOI: 10.1002/sres.393.

5. Association for Computing Machinery (ACM) Web site, http://www.acm.org/ constitution/code.html (accessed August 21, 2007).

6. Association of Independent Information Professionals (AIIP) Web site, http://www. aiip.org/AboutAIIP/aiipethics.html (accessed August 21, 2007). 
7. American Society for Information Science and Technology (ASIS\&T) Web site, http://www.asis.org/AboutASIS/professional-guidelines.html (accessed August 21, 2007).

8. American Society for Public Administration (ASPA) Web site, http://www. aspanet.org/scriptcontent/index_codeofethics.cfm (accessed August 21, 2007).

9. Society of Competitive Intelligence Professionals (SCIP) Web site, http://www. scip.org/2_code.php (accessed August 21, 2007).

10. Society of American Archivists (SAA) Web site, http://www.archivists.org/ governance/handbook/app_ethics.asp (accessed August 21, 2007).

11. American Library Association Web site, http://www.ala.org/ ala/oif/statementspols/ codeofethics/codeethics.htm (accessed August 21, 2007).

12. Esther Green Bierbaum, "Searching for the Human Good: Some Suggestions for a Code of Ethics for Technical Services," Technical Services Quarterly 11(3) (1994), 1-18.

13. ALCTS Acquisitions Section Ethics Task Force, "Statement on Principles and Standards of Acquisitions Practice" (1994), http://www.ala.org/ContentManagement/ ContentDisplay.cfm?ContentID = 162505 (accessed August 21, 2007).

14. Sheila Bair, "Toward a Code of Ethics for Cataloging," Technical Services Quarterly 23(1) (2005), 13. DOI: 10.1300/J124v23n01_02.

15. Edie McCormick, et al., "American Libraries Conference Draws Record Crowd," includes related article, "Council Approves New Code of Ethics," American Libraries 26 (7) (July/Aug 1995), 676.

16. Fay Zipkowitz, Professional Ethics in Librarianship: A Real Life Casebook. (Jefferson, N.C.: McFarland \& Co., 1996).

17. Michael Gorman, "New Libraries, Old Values," Australian Library Journal (February 1999), 46-47.

18. Kenneth G. Peterson, "Ethics in Academic Librarianship: The Need for Values," Journal of Academic Librarianship 9 (3) (1983), 132.

19. Wallace C. Koehler, Jitka M. Hurych, Wanda V. Dole \& Joanna Wall, "Ethical Values of Information and Library Professionals-An Expanded Analysis," International Information \& Library Review 32 (2000), 497. DOI: 10.1006/iilr.2000.0141.

20. Wanda V. Dole, Jitka M. Hurych \& Wallace C. Koehler, "Values for Librarians in the Information Age: An Expanded Examination," Library Management 21 (6) (2000), 285-297.

21. Michael Gorman, "The Wrong Path \& the Right Path: The Role of Libraries in Access to, and Preservation of, Cultural Heritage," Progressive Librarian 28 (Winter 2006/2007), 91.

22. ibid.

23. Britta Santamauro and Katherine C. Adams, "Are We Trained Monkeys or Philosopher-Kings? The Meaning of Catalogers' Judgment," Technicalities 26(5) (September/October 2006), 13.

24. Robert P. Holley, "Cataloging: an Exciting Subject for Exciting Times," Cataloging and Classification Quarterly 34 (1/2) (2002), 46.

25. Cataloging Heresy: Challenging the Standard Bibliographic Product, edited by Bella Hass Weinberg (Medford, NJ: Learned Information, Inc., 1992), 10. 
26 Santamauro, Catalogers' Judgment, 14.

27. Julie Moore Iliff, "Cataloging: It's All about Connecting People with Information," PNLA Quarterly 68(2) (Winter 2004), 15.

28. Bair, Toward a Code of Ethics, 22.

29. Sanford Berman, "Things are Seldom What They Seem: Finding Multicultural Materials in Library Catalogs," in Alternative Library Literature 1990-1991 (Jefferson, N.C.: McFarland \& Co., 1992), 132-136.

30. Karen A. Nuckolls, "Subject Access to Diversity Materials: The Library of Congress Subject Heading Shortfall," The Reference Librarian 45/46 (1994), 241-251.

31. Cataloging Heresy, 18-19.

32. LC Subject Authorities, scope note for LCCN: sh 85013778 (Bible. O.T., Apocrypha).

33. LC Subject Authorities, scope note for LCCN: sh 85006006 (Apocryphal books).

34. Nancy A. Olson, "Cataloging Three-Dimensional Artefacts and Realia," Cataloging and Classification Quarterly 31 (3/4) (2001), 139-150.

35. Joan K. Marshall, On Equal Terms: a Thesaurus for Nonsexist Indexing and Cataloging (New York: Neal-Schuman, 1977).

36. Cataloging Heresy, 161.

37. Cataloging Heresy, 120.

38. Association for Library Collections \& Technical Services, "ALCTS issues statement on the Library of Congress series authority record decision," ALA Web site, http://www.ala.org/ala/pressreleases2006/may2006/ALCTSstatementLCseries.htm (accessed August 21, 2007).

39. Laura B. Cohen, “A Manifesto for Our Times," American Libraries 38(7) (August 2007), 47.

40. Steven A. Knowlton, "Three Decades Since "Prejudices and Antipathies": A Study of Changes in the Library of Congress Subject Headings, Cataloging \& Classification Quarterly 40(2) (2005), 128. DOI: 10.1300/J104v40n02_0842.

41. "Library of Congress Report on Subject Cataloging ALA ALCTS CCS Subject Analysis Committee (SAC)," [SAC07-MID/10], Midwinter Meeting, Seattle, Washington, January 21, 2007 [rev. February 1, 2007], submitted by Lynn El-Hoshy, http://www.ala.org/ala/alctscontent/catalogingsection/catcommittees/subjectanalysis/ sacmw07.doc. (accessed August 21, 2007).

42. Elaine Sanchez and Robert Bratton, "Prevent the Library of Congress from Abandoning the Creation of Series Authority Records," http://www.petitiononline. com/MARC830/petition.html (accessed Aug. 20, 2007).

43. Resource Description and Access, FAQs, "What Happened to AACR3?" http://www.collectionscanada.ca/jsc/rdafaq.html (accessed August 20, 2007).

44. Karen Coyle and Diane Hillman, "Resource Description and Access (RDA): Cataloging Rules for the 20th Century," D-Lib Magazine, 13 (1/2) (January/February 2007).

45. Association for Library Collections \& Technical Services (ALCTS) Cataloging \& Classification Section (CCS) Executive Committee, "The Value of Cataloging Librarians," (June 13, 2006), ALA Web site, http://www.ala.org/ala/alctscontent/ 
alctspubsbucket/webpublications/cataloging/valuecatlibs/0707catlibvalue.htm (accessed 20 Aug, 2007).

46. Coyle and Hillman, RDA.

47. Gorman, Wrong Path, 91.

48. Michael Gorman, "What's It All About? Beyond Equity of Access," American Libraries, 36(10) (November 2005), 5. 